\title{
Avaliação da Floresta Nacional de Brasília para o atendimento de pessoas com deficiência e/ou mobilidade reduzida
}

\section{Jakson Lima do Nascimentoํㅜ, Ronilson José da Paz²}

${ }^{1}$ Floresta Nacional de Brasília. BR-070, km 03, Taguatinga - DF (CEP 72000-000). E-mail: jaksonln@gmail.com.

${ }^{2}$ Instituto Brasileiro do Meio Ambiente e dos Recursos Naturais Renováveis (IBAMA), Caixa Postal 5063, João Pessoa - PB (CEP 58051-900). E-mail: ronilson.paz@gmail.com.

Resumo. Trata o presente artigo sobre a avaliação da Floresta Nacional de Brasília para o atendimento de pessoas com deficiência e/ou mobilidade reduzida, visando a sua inclusão social, permitindo o usufruto do contato com a Natureza. De um modo geral, observou-se que a Floresta Nacional de Brasília não possui estruturas adequadas que possam acolher essas pessoas. Diante disso foi sugerida a realização de algumas adequações de modo a possibilitar o atendimento à legislação, como: implantação de estruturas para a segurança dos visitantes e também estruturas que a tornem mais atrativa para os visitantes, como a implantação de sala de visitantes com exposição de fotos, disponibilização dos animais taxidermizados para as pessoas com deficiência visual, jardim sensorial, passeio ciclístico em bicicletas duplas com as pessoas com deficiência visual, jeep tour para cadeirantes, vôlei adaptado para pessoas com deficiência física, arvorismo para pessoas com deficiência auditiva e mental e trilha interpretativa adaptada para todas as pessoas com deficiência e mobilidade reduzida.

Palavras-chave: Unidade de conservação, Pessoa com deficiência, Mobilidade reduzida, Inclusão social, Educação ambiental.

Abstract. Evaluation of the Brasilia National Forest for the care of people with disabilities and/or reduced mobility. This monograph aims assess the needs of the National Forest Brasilia for the care of people with disabilities and/or reduced mobility, aimed at social inclusion, thus allowing the possibility of these people to enjoy the contact with nature. In general, it was observed that the National Forest of Brasilia not have suitable structures that accommodate these people. Therefore it was suggested to carry out some adjustments in order to enable compliance with legislation, such as the establishment of structures for the safety of visitors and also structures that make it more attractive for visitors, like: visitors room of deployment with exposure photos, availability of stuffed animals for the blind, sensory garden, cycling tour in "double bike" with the blind, jeep tour for wheelchair users, volleyball adapted to disabled, canopy tours for the deaf and mentally, and interpretive trail adapted for all people with disabilities and reduced mobility.

Keywords: Conservation unit, People with disabilities, Reduced mobility, Social inclusion, Environmental education.

Recebido: 22/05/2015

Aceito: 15/06/2015

Publicado: 30/06/2015

Acesso Aberto

Artigo completo

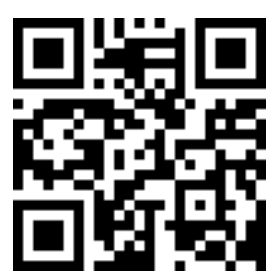




\section{Introdução}

As unidades de conservação são espaços especialmente protegidos por lei, destinadas à proteção e conservação do meio ambiente. Além de cumprirem outras funções importantes, tanto do ponto de vista ambiental, quanto sociocultural, dentre essas a conservação dos recursos ambientais e da biodiversidade como um todo, manutenção do equilíbrio dos ciclos de água e de nutrientes, manutenção da qualidade do ar, além de serem espaços destinados à realização de pesquisas, Educação Ambiental e, até mesmo, o lazer (Santos et al., 2007).

De acordo com a Declaração Universal dos Direitos Humanos de 1948, "todos os seres humanos nascem livres e iguais em dignidade e direitos".

Segundo a Convenção Internacional sobre os Direitos das Pessoas com Deficiência (2007), da qual o Brasil é signatário, pessoa com deficiência:

São aquelas que têm impedimentos de longo prazo de natureza física, mental, intelectual ou sensorial, os quais, em interação com diversas barreiras, podem obstruir sua participação plena e efetiva na sociedade em igualdades de condições com as demais pessoas.

O Manual do Ministério do Meio Ambiente "Diretrizes para Visitação em Unidades de Conservação" (MMA, 2006), diz que se deve considerar no planejamento e na gestão da visitação nas unidades de conservação, quando viável e aplicável, a realização de igualdade de oportunidades. Recomenda também que os profissionais responsáveis pela "concepção e construção de empreendimentos, incluam em seus projetos e obras as intervenções necessárias para garantir a acessibilidade”.

Julião e Ikemoto (2006: 1) afirmam que:

As atividades realizadas em áreas naturais, como exercícios físicos, recreação e contemplação da Natureza proporcionam uma riqueza de estímulos visuais, sonoros, olfativos, táteis e sinestésicos. Além desses benefícios, especialistas e usuários ressaltam que as atividades turísticorecreativas permitem ao deficiente a superação dos seus próprios limites, a promoção da auto-estima, da sua socialização e de uma visão holística sobre os espaços que compõem a cidade, facilitando a formação do sujeito, a compreensão e orientação espacial.

Muitas dessas atividades nas unidades de conservação são inacessíveis às pessoas com deficiência, ou mesmo, às pessoas com mobilidade reduzida, como é o caso dos idosos, crianças ou gestantes. Segundo Malaggi (2011), com algumas adaptações, preparo de profissionais e assistência adequada, as atividades poderiam ser mais acessíveis, proporcionando uma maior conscientização ambiental e por consequência ainda promover a preservação e conservação desses ambientes.

Sendo assim, o respeito à legislação, mais ainda o respeito ao ser humano não pode ser negligenciado pelas autoridades, as quais, cabe a gestão de programas e projetos de Educação Ambiental que são desenvolvidos nas unidades de conservação para permitir a visitação. Devem contemplar a todos, inclusive idosos, crianças, gestantes e as pessoas com deficiências.

Segundo o Ministério do Turismo (2010: 13)

A acessibilidade é um tema que está cada vez mais em evidência no Brasil. São notáveis os avanços da legislação específica sobre os direitos das pessoas com deficiência ou mobilidade reduzida na última década e têm crescido os esforços para garantir o acesso dessas pessoas a todos os bens e serviços com segurança e autonomia, em todos os aspectos da vida social. Embora haja ainda muito a ser feito para que a legislação vigente seja de fato implementada, essas mudanças indicam um amadurecimento da sociedade brasileira sobre o tema, além - é claro - de ser o resultado da luta das pessoas com deficiência por seus direitos. 


\section{Educação Ambiental}

A Natureza deve ser tratada como um ente querido, com o qual temos atitudes de proteção, carinho e respeito (Line e Mergulhão 2014).

Para Line e Mergulhão (2014), com o advento da revolução industrial, houve um aumento da exploração dos recursos naturais, culminando com o modelo capitalista, movido pela satisfação do homem. O uso desenfreado e inconsequente dos recursos naturais provocou diversas transformações ambientais com influências diretas e indiretas na vida de todos, tais como a extinção de espécies, o aparecimento de animais sinantrópicos, pragas, doenças e falta de recursos hídricos.

Após a Segunda Guerra Mundial, principalmente a partir da década de 1960, intensificou-se a percepção de que a humanidade pode caminhar aceleradamente para o esgotamento ou a inviabilização de recursos indispensáveis a sua própria sobrevivência. E que algo deveria ser feito para alterar as formas de ocupação do planeta estabelecidas pela cultura dominante. Esse tipo de constatação gerou o movimento de defesa do meio ambiente, que luta para diminuir o acelerado ritmo de destruição dos recursos naturais ainda preservados e busca alternativas que conciliem, na prática, a conservação da Natureza com a qualidade de vida das populações que dependem dessa Natureza (Brasil, 1997).

Diante disso, o reconhecimento do papel da educação para a formação de uma nova consciência e postura ambiental foi um grande passo na busca de um desenvolvimento sustentável (Carvalho, 2008). No entendimento de Paz (2006b), a relação homem-Natureza deve ser repensada e a Educação Ambiental tem um papel preponderante nessa tarefa.

Segundo Dias (2001: 148):

A educação ambiental é considerada um processo permanente pelo qual os indivíduos e a comunidade tomam consciência do seu meio ambiente e adquirem o que os tornam aptos a agir - individual e coletivamente -e resolver problemas ambientais presentes e futuro.

Para Line e Mergulhão (2014), a educação é o processo de construção humana que tem a função de formar uma sociedade com valores, ideologias e saberes que permitam a avaliação, a compreensão e a transformação da realidade.

De acordo com 0 art. $1^{\circ}$, da Lei $n^{\circ}$ 9.795/1999, que institui a Política Nacional de Educação Ambiental:

Entende-se por educação ambiental os processos por meio dos quais o indivíduo e a coletividade constroem valores sociais, conhecimentos, habilidades, atitudes e competências voltadas para a conservação do meio ambiente, bem de uso comum do povo, essencial à sadia qualidade de vida e sua sustentabilidade.

Para a Lei $n^{0}$ 9.975/1999, a Educação Ambiental deve estar presente, de forma articulada, em todos os níveis e modalidades do processo educativo, em caráter formal e não-formal, devendo ainda ser um componente essencial e permanente da educação nacional. Neste contexto é importante, que haja uma sensibilização da sociedade para a importância das unidades de conservação no processo de ensinoaprendizagem não-formal da Educação Ambiental.

De acordo com a Lei no 9.975/1999, são princípios básicos da Educação Ambiental:

I - o enfoque humanista, holístico, democrático e participativo;

II - a concepção do meio ambiente em sua totalidade, considerando a interdependência entre o meio natural, o sócio-econômico e o cultural, sob o enfoque da sustentabilidade;

III - o pluralismo de idéias e concepções pedagógicas, na perspectiva da inter, multi e transdisciplinaridade;

IV - a vinculação entre a ética, a educação, o trabalho e as práticas sociais;

$\mathrm{V}$ - a garantia de continuidade e permanência do processo educativo;

VI - a permanente avaliação crítica do processo educativo;

VII - a abordagem articulada das questões ambientais locais, regionais, nacionais e globais;

VIII - o reconhecimento e o respeito à pluralidade e à diversidade 
individual e cultural. (art. $4^{\circ}$, Lei $\mathrm{n}^{\circ}$ 9.975/1999).

Ainda, de acordo com a Lei $\mathrm{n}^{\circ}$ 9.975/1999, são objetivos fundamentais da educação ambiental:

I - o desenvolvimento de uma compreensão integrada do meio ambiente em suas múltiplas e complexas relações, envolvendo aspectos ecológicos, psicológicos, legais, políticos, sociais, econômicos, científicos, culturais e éticos;

II - a garantia de democratização das informações ambientais;

III - o estímulo e o fortalecimento de uma consciência crítica sobre a problemática ambiental e social;

IV - o incentivo à participação individual e coletiva, permanente e responsável, na preservação do equilíbrio do meio ambiente, entendendo-se a defesa da qualidade ambiental como um valor inseparável do exercício da cidadania;

V - o estímulo à cooperação entre as diversas regiões do País, em níveis micro e macrorregionais, com vistas à construção de uma sociedade ambientalmente equilibrada, fundada nos princípios da liberdade, igualdade, solidariedade, democracia, justiça social, responsabilidade e sustentabilidade; VI - o fomento e o fortalecimento da integração com a ciência e a tecnologia;

VII - o fortalecimento da cidadania, autodeterminação dos povos e solidariedade como fundamentos para o futuro da humanidade. (art. $5^{\circ}$, Lei ${ }^{\circ}$ 9.975/1999).

Os princípios e objetivos básicos da Educação Ambiental devem nortear todas as ações a serem desenvolvidas nas unidades de conservação que tem entre os seus objetivos, o de "favorecer condições e promover a educação e interpretação ambiental, a recreação em contato com a Natureza e o turismo ecológico" (art. $4^{\circ}$, XII, Lei $n^{\circ}$ 9.985/2000). Ou seja, entre outras coisas, deve buscar construir uma sociedade ambientalmente equilibrada, fundada nos princípios da liberdade, igualdade, solidariedade, democracia, justiça social, responsabilidade e sustentabilidade.

\section{Pessoas com deficiência e/ou mobilidade reduzida}

Para os efeitos do Decreto $\mathrm{n}^{\circ}$ $3.298 / 1999$, que regulamenta a integração das pessoas com deficiência, deficiência é "toda perda ou anormalidade de uma estrutura ou função psicológica, fisiológica ou anatômica que gere incapacidade para o desempenho de atividade, dentro do padrão considerado normal para o ser humano”.

Atualmente, o termo considerado mais apropriado para o trato com essas pessoas é "pessoa com deficiência" e não mais "portador de deficiência", ressaltando e valorizando a pessoa, não mais colocando à frente suas limitações, independente delas serem física, mental, auditiva ou visual (Sassaki, 2003; Paz, 2006a).

Segundo Convenção Internacional sobre os Direitos das Pessoas com Deficiência, assinados em Nova York, em 30 de março de 2007, da qual o Brasil é signatário, tendo ratificado-a por meio do Decreto $\mathrm{n}^{\circ}$ 6.949/2009, pessoas com deficiência:

São aquelas que têm impedimentos de longo prazo de natureza física, mental, intelectual ou sensorial, os quais, em interação com diversas barreiras, podem obstruir sua participação plena e efetiva na sociedade em igualdades de condições com as demais pessoas. (Resende e Vital, 2008).

Segundo Oliveira (2012), constituem as fontes das garantias de realização dos direitos humanos a todos os cidadãos a Declaração Universal dos Direitos Humanos, os tratados e convenções específicos e a legislação criada no país para implementar políticas que atendam às exigências de tratados internacionais.

De acordo com Oliveira (2012):

Os direitos da pessoa com deficiência podem ser acionados tanto com base no direito fundamental do ser humano como com base nas características próprias desse segmento populacional. $\mathrm{Na}$ 
prática, a realização dos direitos das pessoas com deficiência exige ações em ambas as frentes, a do direito universal e a do direito de grupos específicos, tendo sempre como objetivo principal minimizar ou eliminar a lacuna existente entre as condições das pessoas com deficiência e as das pessoas sem deficiência.

O Decreto $n^{\circ} 3.298 / 1999$, alterado pelo Decreto $n^{0} 5.296 / 2004$, categoriza os vários tipos de deficiências da seguinte maneira:

I - deficiência física - alteração completa ou parcial de um ou mais segmentos do corpo humano, acarretando o comprometimento da função física, apresentando-se sob a forma de paraplegia, paraparesia, monoplegia, monoparesia, tetraplegia, tetraparesia, triplegia, triparesia, hemiplegia, hemiparesia, ostomia, amputação ou ausência de membro, paralisia cerebral, nanismo, membros com deformidade congênita ou adquirida, exceto as deformidades esteticas e as que não produzam dificuldades para o desempenho de funções;

II - deficiência auditiva - perda bilateral, parcial ou total, de quarenta e um decibéis $(\mathrm{dB})$ ou mais, aferida por audiograma nas frequências de $500 \mathrm{HZ}, \quad 1.000 \mathrm{HZ}, \quad 2.000 \mathrm{~Hz}$ e $3.000 \mathrm{~Hz}$;

III - deficiência visual - cegueira, na qual a acuidade visual é igual ou menor que 0,05 no melhor olho, com a melhor correção óptica; a baixa visão, que significa acuidade visual entre 0,3 e 0,05 no melhor olho, com a melhor correção óptica; os casos nos quais a somatória da medida do campo visual em ambos os olhos for igual ou menor que $60^{\circ}$; ou a ocorrência simultânea de quaisquer das condições anteriores;

IV - deficiência mental - funcionamento intelectual significativamente inferior à média, com manifestação antes dos dezoito anos e limitações associadas a duas ou mais áreas de habilidades adaptativas, tais como:

a) comunicação;

b) cuidado pessoal;

c) habilidades sociais;

d) utilização dos recursos da comunidade; e) saúde e segurança;

f) habilidades acadêmicas;

g) lazer; e

h) trabalho.

V - deficiência múltipla - associação de duas ou mais deficiências.

Os dados do Instituto Brasileiro de Geografia e Estatística (IBGE), no Censo Demográfico de 2000, mostravam que $14,5 \%$ da população tinham alguma deficiência, fosse ela visual, auditiva, motora e mental ou intelectual. Já nos dados de 2010, houve um salto para 23,9\%. Possivelmente esse aumento pode ser explicado pela mudança de paradigma de aceitação da própria deficiência, já que o método do IBGE leva em consideração a percepção dos entrevistados.

Segundo a análise dos dados do IBGE por Oliveira (2012), a proporção de pessoas que apresentou deficiências severas era de $8,3 \%$ da população.

De modo geral, a deficiência atinge pessoas de todas as idades, porém é interessante observar que, segundo o Censo do IBGE (2010), a proporção de pessoas com deficiência é maior entre o grupo maior de 65 anos.

A deficiência visual teve maior prévalência em todos os grupos de idade, sendo bastante acentuada no grupo acima de 65 anos, ocorrendo em quase a metade da população desse segmento (49,8\%). Para esse grupo, a deficiência motora é a segunda mais frequente, ocorrendo em 38,3\%, seguida pela auditiva, em $25,6 \%$, e mental ou intelectual, em 2,9\%.

Estes dados mostram que há uma parcela considerável da população com deficiência e que esta parcela aumenta ainda mais entre os idosos, Pois, mesmo os idosos que não apresentam qualquer deficiência fazem parte do grupo de pessoas com mobilidade reduzida, assim definida:

$\S 1^{\circ}$ Aquela que, não se enquadrando no conceito de pessoa [com] deficiência, tenha, por qualquer motivo, dificuldade de movimentarse, permanente ou temporariamente, gerando redução efetiva da mobilidade, flexibilidade, coordenação motora e percepção.

$\S 2^{\circ} \mathrm{O}$ disposto no caput aplica-se, ainda, às pessoas com idade igual ou superior a sessenta anos, gestantes, 
lactantes e pessoas com criança de colo. (art. 5 ${ }^{\circ}$ II, Decreto $n^{\circ}$ 5.296/2004).

Além disso, segundo o Ministério do Turismo (2010: 16):

podemos acrescentar a essa lista as pessoas que sofreram algum tipo de acidente e, por conta disso, apresentam limitações temporárias de mobilidade. Todas essas pessoas frequentemente necessitam de alguma solução de acessibilidade seja no trabalho, no transporte público, em edificações e espaços urbanos, em instituições de saúde e educação, em prédios e serviços da administração pública, em estabelecimentos comerciais e de lazer etc.

\section{Para Oliveira (2012, p. 28):}

Os problemas que as pessoas com deficiência encontram na realização de seus direitos são problemas que concernem a todos nós, brasileiros. A Constituição Federal garante aos indivíduos o desenvolvimento pleno no aprendizado, no trabalho e no acesso aos direitos nela estabelecidos. A visão de direitos humanos é baseada na não discriminação e se sustenta em três pilares principais: igualdade de oportunidade, poder de decisão sobre a própria vida e segurança para exigir os direitos. $\mathrm{O}$ desenvolvimento sustentável do país depende da inclusão de todas as pessoas, do trabalho de todos, não sendo permitido que indivíduos ou grupos fiquem fora do processo. Um meio ambiente adaptado às diferenças permite que as pessoas com deficiência realizem suas aspirações, seus desejos e seu desenvolvimento pleno. Além disso, para que os direitos humanos sejam realizados de forma universal, os tratados internacionais de direitos humanos precisam ser observados por uma estrutura de monitoramento e um sistema judicial efetivo.

Julião e Ikemoto (2006) afirmam que "as atividades realizadas em áreas naturais, como exercícios físicos, recreação e contemplação da Natureza proporcionam uma riqueza de estímulos visuais, sonoros, olfativos, táteis e sinestésicos”.

Neste contexto, Oliveira (2013) observa que a inclusão de pessoas com deficiência em áreas naturais para atividades físicas ou simplesmente pelo contato com a Natureza pode permitir que elas "reflitam sobre o meio que estão inseridos e se sociabilizem, desenvolvendo valores, hábitos e atitudes com vista à conservação dos recursos naturais e uma nova forma de integração a sociedade.”

A utilização de lugares que tenham propostas de Educação Ambiental, como parques e unidades de conservação, é uma maneira de alcançar essa socialização de forma que cause interesse no aluno e nas pessoas como um todo, pois torna uma maneira nova e divertida de ver o mundo, muitas vezes ocorrendo de forma marcante. Esses locais estimulam o raciocínio e facilitam a integração de diversos temas, explorando diversos sentidos (Mergulhão e Vasaki, 1998).

Segundo Moriwaki e Neiman (2011), há muitas vezes confusão quando se usam os termos inclusão social e integração social. Na integração, aceita-se incorporar a pessoa com deficiência, porém somente aqueles que conseguem se adaptar aos obstáculos por mérito próprio. Já na inclusão, reconhece-se a existência da desigualdade e não se nega a necessidade de um tratamento diferenciado, pelo contrário, sendo exatamente este tratamento diferenciado que poderá promover o acesso aos mesmos direitos.

Para o Ministério do Turismo (2010: 13):

Devemos lembrar que pessoas com deficiência ou mobilidade reduzida devem ser respeitadas em suas particularidades e compreender que algumas de suas necessidades podem - e frequentemente são - diferentes das necessidades de pessoas que não estão nessas condições. É por isso que dizemos que se não promovemos a acessibilidade, estamos perpetuando a discriminação.

Ou seja, devemos seguir a lógica Aristotélica de "tratar igualmente os iguais e desigualmente os desiguais, na medida de sua desigualdade". 


\section{Sistema Nacional de Unidades de Conservação}

A Lei $\mathrm{n}^{0}$ 9.985/2000 (art. $4^{\circ}$ ), que cria o Sistema Nacional de Unidades de Conservação da Natureza (SNUC), define como um dos objetivos das Unidades de Conservação o de "favorecer condições e promover a educação e interpretação ambiental, a recreação em contato com a natureza e o turismo ecológico" (Paz et al., 2006; Paz et al., 2008).

O SNUC prevê 12 categorias de Unidades de Conservação, organizando-as de acordo com seus objetivos de manejo e tipos de uso em dois grandes grupos: de proteção integral ou de uso sustentável.

As Unidades de proteção integral que têm como objetivo básico a preservação da Natureza, sendo admitido o uso indireto dos seus recursos naturais. São elas: Estação Ecológica (ESEC), Reserva Biológica (REBIO), Parque Nacional (PARNA), Monumento Natural (MONA), e Refúgio de Vida Silvestre (RVS).

As Unidades de uso sustentável visam compatibilizar a conservação da natureza com o uso direto de parcela dos seus recursos naturais. Ou seja, são aquelas que permitem a exploração do ambiente, porém mantendo a biodiversidade do local e os seus recursos renováveis. São elas: Área de Proteção Ambiental (APA), Área de Relevante Interesse Ecológico (ARIE), Floresta Nacional (FLONA), Reserva Extrativista (RESEX), Reserva de Fauna; Reserva de Desenvolvimento Sustentável (RDS), e Reserva Particular do Patrimônio Natural (RPPN).

A Floresta Nacional é, portanto, uma unidade de conservação de uso sustentável, que é definida, de acordo com a Lei $n^{\circ}$ 9.985/2000 (art. 17), como “uma área com cobertura florestal de espécies predominantemente nativas e tem como objetivo básico o uso múltiplo sustentável dos recursos florestais e a pesquisa científica, com ênfase em métodos para exploração sustentável de florestas nativas” (Paz et al., 2008).

Sua posse e domínio devem ser públicos, sendo que as áreas particulares incluídas em seus limites devem ser desapropriadas. É admitido, porém, quando presentes, a presença de populações tradicionais. Podem incluir a proteção de recursos hídricos, de belezas cênicas e de sítios históricos e arqueológicos, assim como a educação ambiental e as atividades de recreação, lazer e turismo.

A Lei ${ }^{\circ} 9.985 / 2000$ (art. 17, § $3^{\circ}$ ) estabelece que a visitação pública é permitida. Sendo condicionada às normas estabelecidas para o manejo da unidade pelo órgão responsável por sua administração.

As Florestas Nacionais devem dispor de um conselho consultivo, os quais se constituem de representantes de órgãos públicos, de organizações da sociedade civil e, quando presentes, das populações tradicionais residentes. A presidência de um conselho consultivo, contudo, é reservada ao órgão responsável pela administração da respectiva floresta nacional.

No âmbito Federal, a execução das ações do SNUC sobre as unidades de conservação, entre elas as florestas nacionais é de responsabilidade do Instituto Chico Mendes de Conservação da Biodiversidade (ICMBio), devendo assim propor, implantar, gerir, proteger, fiscalizar e monitorar.

Em 2006, o Ministério do Meio Ambiente (MMA), por meio da Secretaria de Biodiversidade e Florestas, editou um livro intitulado "Diretrizes para Visitação em Unidades de Conservação". No que concernem as diretrizes para atividades a serem realizadas por "portadores de necessidades especiais”, (MMA 2006) define que o ICMBio deve:

Observar e atender à legislação e às normas específicas para a promoção da acessibilidade de pessoas portadoras de necessidades especiais. Considerar no planejamento e gestão da visitação nas UC, quando viável e aplicável, a realização da igualdade de oportunidades, que diz respeito ao processo mediante o qual serviços, atividades, informação e documentação são postos à disposição de todos.

Assegurar que arquitetos, engenheiros civis e outros profissionais responsáveis pela concepção e construção de empreendimentos incluam em seus projetos e obras as intervenções necessárias para garantir a acessibilidade. 
Consultar as organizações de pessoas portadoras de necessidades especiais durante a elaboração de padrões e normas de acessibilidade, desenvolvendo atividades e produtos específicos para este público.

Apesar das diretrizes terem sido publicadas em 2006, ainda há unidades de conservação que ainda não aplicam essas diretrizes.

Assim, esse trabalho visa a fazer um diagnóstico da acessibilidade na Floresta Nacional de Brasília - Flona de Brasília (ICMBio, s.d.). Busca ainda conhecer o que vem sendo desenvolvido em Unidades de Conservação e espaços abertos para permitir a acessibilidade de pessoas com deficiência para visando uma análise crítica sobre quais adaptações e ou atividades são possíveis de serem implantadas na Flona de Brasília.

\section{Material e métodos}

A realização do trabalho foi baseado numa pesquisa qualitativa, tendo como referências o estudo das normas (leis e decretos), a pesquisa indireta de adaptações, atividades e projetos desenvolvidos em unidades de conservação e áreas abertas, bem como a pesquisa direta, por meio de visitas de campo realizadas no Parque Nacional de Brasília e no Jardim Botânico de Brasília e na Floresta nacional de Brasília entre janeiro e maio de 2015.

O diagnóstico de acessibilidade da Floresta Nacional de Brasília, foi realizado considerando-se as orientações de Sandoval (2002: 19-20).

\section{Floresta Nacional de Brasília}

A Floresta Nacional de Brasília foi criada pelo Decreto $\mathrm{s} / \mathrm{n}$ de 10 de junho de 1999, que autorizou a União a aceitar a doação de imóveis que lhe faz a Companhia Imobiliária de Brasília (TERRACAP).

Esta Flona surgiu do compromisso do Governo do Distrito Federal de doar os imóveis que compõem sua área à União, com o intuito de criação desta unidade de conservação.

Esta é uma unidade de conservação de uso sustentável, que tem o objetivo de:
Promover o manejo de uso múltiplo e de forma sustentável dos recursos naturais renováveis, a manutenção e proteção dos recursos hídricos e da biodiversidade do Cerrado, a recuperação de áreas degradadas, a educação florestal e ambiental, a manutenção de amostras do fragmento do ecossistema e o apoio ao desenvolvimento sustentável dos recursos naturais das áreas limítrofes. (Brasil, 1999).

A Flona de Brasília é composta por quatro áreas descontínuas (Figura 1), que totalizam 9.346 ha. Localizando-se a Área 1 e 2 na Região Administrativa de Taguatinga e as Áreas 3 e 4 na Região Administrativa de Brazlândia. É, segundo Coelho (2007), responsável pela proteção de mananciais que abastem grande parte de Brasília por estar inseria na Bacia do Rio Descoberto.

A Área 1 possui $3.353,18$ ha e, envolvendo o Ribeirão das Pedras, localizase entre o Córrego Currais, e as Rodovias BR-070 e a DF-001. No local ocorrem reflorestamentos com algumas variedades de Eucaliptus e de Pinus, além de fitofisionomias de cerrado, principalmente em área de preservação permanente envolvendo as nascentes dos Córregos Currais e Pedras. É, segundo Coelho (2007), corroborado pela constatação em campo, a área mais preservada da Flona de Brasília.

A Área 2 tem 996,48 ha e está localizada entre a Rodovia DF-001 e os Córregos Cana do Reino, Cabeceira do Vale e Poço d'Água. Encontrasse tomada por um assentamento denominado "26 de Setembro". A área vem sofrendo nos últimos anos com o parcelamento irregular de chácaras pré-existente, com ocupação desordenada e predatória (Coelho, 2007).

A Área 3 tem 3.071 ha e está localizada entre a Rodovia DF-180, em frente à Brazlândia e ao Rio Descoberto, por meio do qual faz limite com o Estado de Goiás. É dividida em talhões, com chácaras "regularizadas" na parte conhecida como Capãozinho, e invasões na parte sul, conhecida como Maranata (Coelho, 2007).

A Área 4 possui 1.925,62 ha e está localizada entre as Rodovias DF-435 e DF-415, envolvendo os córregos Capão da Onça, Barrocão, Jatobá e Guariroba. 


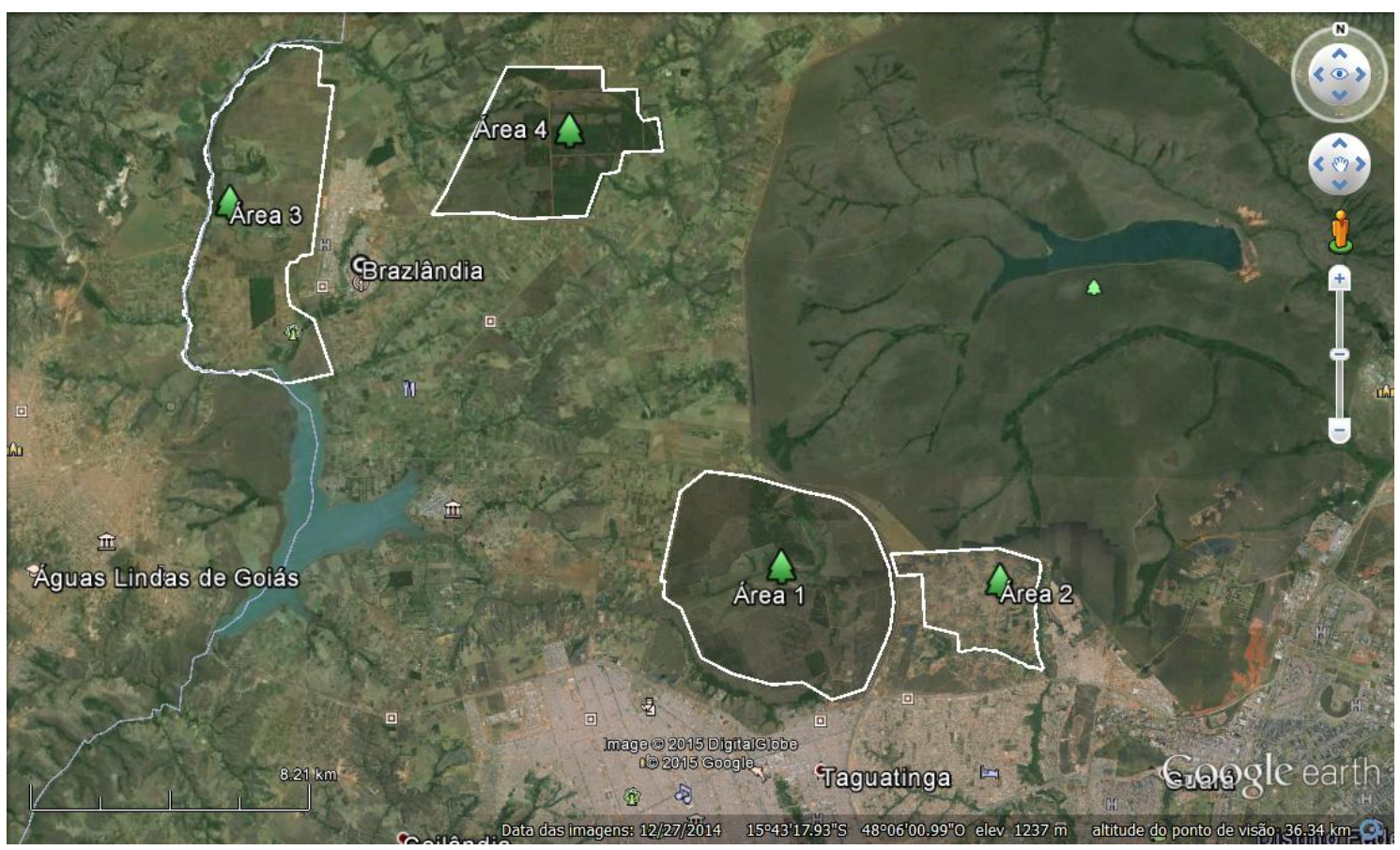

Figura 1. Imagem de satélite mostrando as quatro áreas da Floresta Nacional de Brasília. Fonte: Site do ICMBio.

Representa a segunda área mais conservada da Flona de Brasília, segundo Coelho (2007).

A Flona de Brasília possui dez servidores lotados, sendo dois analistas ambientais, e oito técnicos administrativos; mais o chefe, que é analista ambiental e acumula as chefias da Flona de Brasília e da APA da Bacia do Rio Descoberto APARDE. Cinco dos oito técnicos administrativos estão em vias de aposentadoria nos próximos três anos.

Conta com equipe de vigilância fixa, 24 h, no portão de entrada e no prédio da sede administrativa. Têm ainda outros três servidores terceirizados que cuidam da limpeza das áreas externas e das instalações da sede. Durante o período de seca no Distrito Federal, há uma equipe de servidores temporários de 14 brigadistas de combate a incêndios florestais.

O foco deste trabalho é na Área 1, que é a maior e mais bem preservada das quatro áreas. Isso se justifica por ser a única área com instalações administrativas e também a única usada atualmente para atividades de ecoturismo, recreação, lazer e educação ambiental.

A Área 1 da Floresta Nacional de Brasília recebeu, segundo dados de sua administração, 21.872 visitantes no último ano (2014), um aumento de mais de $100 \%$, se comparado a média dos três anos anteriores de 9.576 visitantes. A maior parte dos visitantes (cerca de 90\%) frequenta o local nos fins de semana para andar de bicicleta, fazerem caminhada e corrida, inclusive com eventos de competição e passeios ciclísticos.

\section{Resultados}

Segundo Sandoval (2002), para que as pessoas com deficiência possam ter acesso às áreas protegidas, a administração do local deve cumprir os seguintes direitos: acesso ao transporte e ao espaço físico, direito à informação, sinalização e comunicação, direito à educação; direito a sentir-se seguro e direito ao acesso à cultura, esporte e recreação. O diagnóstico de acessibilidade foi feito baseado nestes quesitos.

\section{físico \\ Acessos ao transporte e ao espaço \\ Por ser uma área muito próxima à cidade Satélite de Taguatinga, a Área 1 da Flona de Brasília tem fácil acesso de carro e aparentemente poderia tê-lo por meio de}


transporte público. Porém, há uma grande dificuldade para atravessar a Rodovia BR-070. Não há uma passarela próxima à entrada e a via com três faixas de rolamento em cada sentido separada por guard rail com apenas uma pequena passagem. Isso dificulta a travessia, porém praticamente inviabiliza que as pessoas com deficiência tenham acesso com segurança à sede, se não por meio de carro.

A Área 1 tem uma sede administrativa de cerca de $250 \mathrm{~m}^{2}$; estacionamento e pista asfaltada de $1 \mathrm{~km}$, dois viveiros para plantio de mudas, um depósito de ferramentas, combustíveis e materiais diversos; uma casa de madeira usada de maneira improvisada pelos brigadistas florestais e pelos vigilantes. Possui ainda com dois banheiros externos (masculino e feminino) usados pelos visitantes.
Há também os prédios das sedes da Área de Proteção da Bacia do Rio Descoberto e o Centro de Triagem de Animais Silvestres (Cetas), do Instituto Brasileiro de Meio Ambiente e Recursos Naturais Renováveis (Ibama). Essas instalações apresentam gestões independentes.

O prédio da sede da Flona de Brasília (Figura 2) foi construído no ano de 2001, há rampas de acessos no prédio e portas largas, permitindo que cadeirantes e pessoas com mobilidade reduzidas possam acessá-lo com facilidade, porém não há piso podotátil para os deficientes visuais. Conta com quatro salas usadas pelos servidores para as atividades administrativas; cozinha; copa; área de serviços; três banheiros, sendo um deles adaptado para cadeirantes, porém, hoje é usado para guardar equipamento da rede de informática e como depósito.

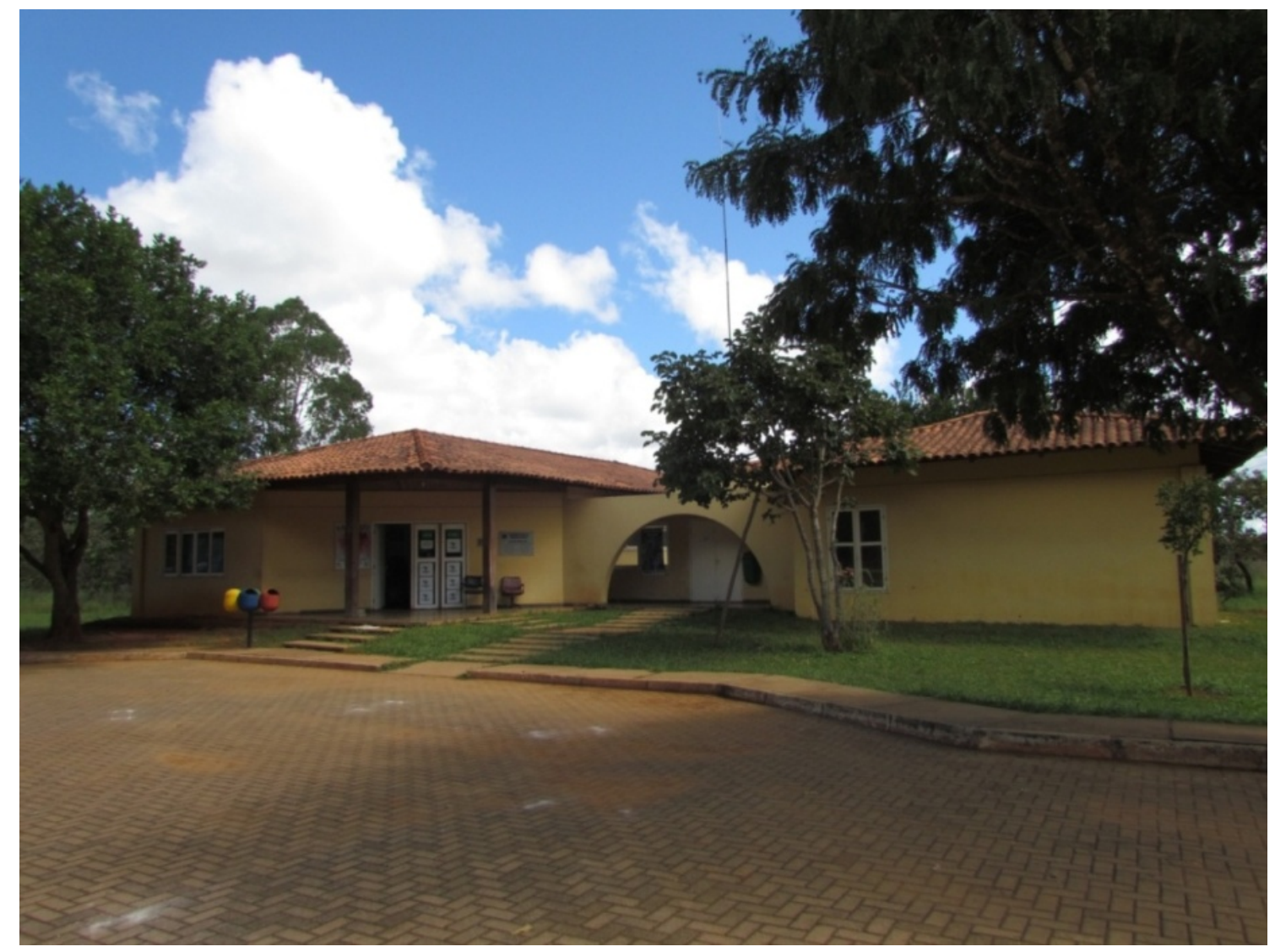

Figura 2. Vista frontal da Sede da Flona de Brasília.

O prédio da sede conta ainda com uma sala maior, que está sendo reformada, será usada para reuniões e para encontros de educação ambiental. Servirá como um centro de recepção de visitantes onde abrigará uma exposição permanente de 
fotos tiradas no interior da Flona de Brasília e de animais taxidermizados. Não há, e segundo a administração mesmo com a reforma, não haverá piso podotátil nem placas em Braille por falta de recursos orçamentários.

Os banheiros externos, que são os usados preferencialmente pelos visitantes, não têm qualquer adaptação, não há barras de apoio, espaço para vestiário, piso podotátil e suas portas são de apenas $60 \mathrm{~cm}$, o que inviabiliza o uso por cadeirantes.

Os dois viveiros, o depósito e a casa de madeira usada pelos brigadistas florestais e vigilantes são instalações precárias e não têm qualquer adaptação que permita acessibilidade, seja de pessoas com deficiência ou com mobilidade reduzida.

A Flona de Brasília possui dois estacionamentos para cerca de 20 carros. Como nos fins de semana ocorre a entrada de mais de 200 carros as margens da pista asfaltada são usadas como estacionamento (Figura 3). Não há, no entanto, reserva de vagas para deficientes e idosos, conforme determinam as Resoluções $n^{\circ}$ 303/2088 e 304/2008, do Conselho Nacional de Trânsito (Contran).

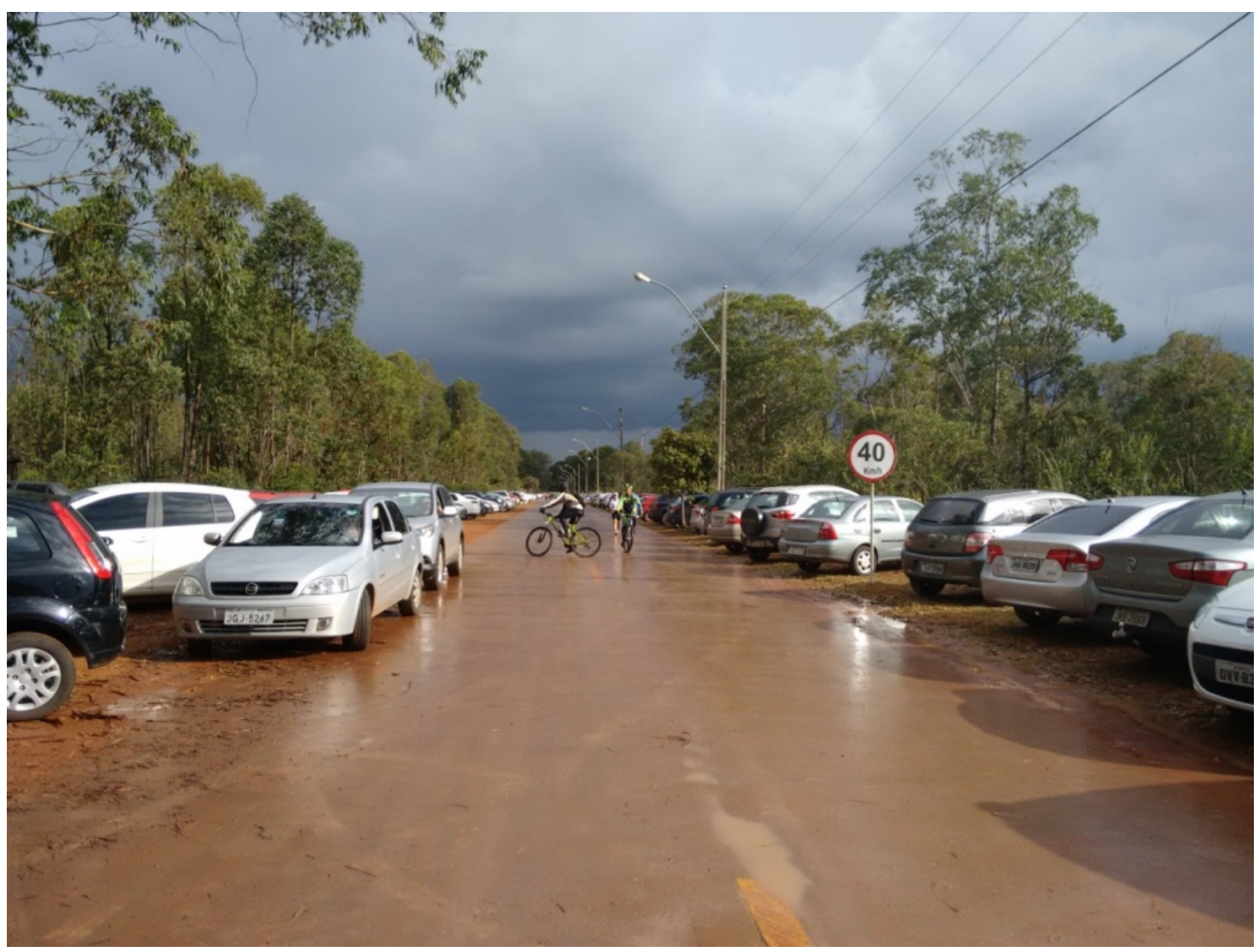

Figura 3. Estacionamento ao longo da pista asfaltada.

Com relação aos acessos aos espaços físicos, há ainda uma observação muito pertinente que é a de não haver bebedouros adaptados para cadeirantes. $\mathrm{O}$ bebedouro do prédio da sede fica muito alto e o instalado próximo à casa usada pela vigilância e brigada florestal além de ser alto não há rampas de acesso.

\section{Direito à informação, sinalização e comunicação}

Na Flona de Brasília há algumas placas educativas, próximo a entrada, ao longo da via asfaltada e da Sede, porém as trilhas e estradas usadas pelos usuários não tem qualquer sinalização, seja ela de localização ou distância percorrida. 
Foi criado pelos servidores um mural do usuário, onde as pessoas podem visualizar mapas e imagens de Satélite e notícias sobre a UC, porém, a única placa informativa convencional mostrando a localização atual esta totalmente ilegível, tampouco não há mapa em Braile ou em alto relevo.

Nenhum dos servidores está habilitado a usar LIBRAS, que é a língua dos sinais, ou a ler em Braille.

\section{Direito à educação}

A Flona de Brasília ainda não possui um programa de Educação Ambiental, no entanto, algumas atividades já são desenvolvidas pela própria unidade ou em parcerias com escolas próximas, Organização Não Governamental (Ong) e Organização Social de Interesse Público (Oscip).

Entre as atividades de Educação Ambiental destacam-se o trabalho realizado pelos servidores com professores da rede pública de ensino, que após sensibilização por meio de palestras e visitas a alguns pontos da Área 1 da Flona, foram convidados a desenvolver atividades com seus alunos de modo a buscar uma interação com o meio ambiente. Também foi importante a parceria com a Oscip Rede de Sementes do Cerrado, que durante três dias desenvolveu o projeto "Semeando o Bioma Cerrado" com alunos da rede pública. O projeto contou com oficinas diversas, percurso de trilha interpretativa e palestras de sensibilização ambiental.

Nenhum projeto, no entanto, buscou a inclusão de alunos que fossem deficientes.

\section{Direito a sentir-se seguro}

A Flona de Brasília conta com vigilância patrimonial $24 \mathrm{~h}$ no portão de entrada

Além desses, há apenas um servidor que é Agente de Fiscalização Ambiental Federal, possue porte de armas e também auxiliam na segurança e na fiscalização da unidade.

Os servidores da Flona e a Polícia Militar, também fazem ronda nos locais que são usados pelos ciclistas. A segurança na Flona é eficiente, considerando que desde a sua criação não houve nenhum incidente digno de nota.

A questão de sentir-se seguro, segundo Sandoval (2002), esta também ligada à questão da comunicação, da sinalização das trilhas e das ações em caso de emergência.

Sendo a Flona de Brasília um ambiente natural e como tal sujeita a acontecer acidentes diversos, inclusive com animais peçonhentos, o tempo de resposta e maneira como ela pode se dar pode ser muito relevante. Os servidores não estão habilitados a usar LIBRAS, que é a língua dos sinais, como poderiam se comunicar com deficientes auditivos em casos de emergência. Tampouco foram capacitados a executar ações de primeiros socorros em área de floresta. Não há posto médico, não há sinalização nas trilhas, não há placas informativas de localização ou qualquer informação sobre o que fazer ou para quem ligar em caso de emergência.

Se tudo isso dificulta os visitantes desfrutarem de uma visita segura, o que dirá se o visitante tiver alguma deficiência, pois muitas vezes a simples comunicação pode fazer a diferença entre a vida ou a morte.

\section{Direito ao acesso à cultura, esporte e recreação}

Dos diversos eventos esportivos que acontecem na Flona de Brasília, tais como corridas a pé e de bicicletas, bem como as atividades de recreação junto à natureza nenhuma atividade até o presente foi desenvolvida com foco nas pessoas com deficiências.

Elas até podem ter se integrado às atividades, porém não houve inclusão social, uma vez que seus direitos, até os mais simples de ir e vir, ou de ter um banheiro adequado, por exemplo, foram negligenciados.

\section{Discussão}

\section{Experiências positivas de acessibilidade em unidades de conservação $e$ áreas naturais}

Para uma apresentação mais didática as observações das adaptações foram separadas para atividades mais relevantes aos tipos de deficiências: visual, motora, auditiva, mental ou intelectual. Não 
significa, porém que outros tipos de deficiências não possam aproveitar das estruturas ou experiências umas das outras.

\section{Visual}

Segundo Line e Mergulhão (2014, p. 1), “a experiência sensitiva é a melhor maneira de captação de conhecimento do deficiente visual, portanto é por meio do desenvolvimento e estimulação constante dos sentidos que assimilações de objetos e espaços irão ocorrer". Nesse sentido as experiências aqui captadas buscaram compreender a melhor maneira de tornar acessível aos deficientes o contato sensitivo com a natureza, fazendo com que as imagens mentais construídas por meio da descrição das pessoas, nem sempre claras, pudessem se aproximar mais da realidade.

A Associação Sorocabana de Atividades para Deficientes Visuais (ASAC) em parceria com o Zoológico local realizou um trabalho com nove crianças, de idades entre 7 a 13 anos, com deficiências visuais. "Foram utilizados, animais taxidermizados como Tamanduá Mirim, Tartaruga Marinha, Tucano Toco, Papagaio-verdadeiro, Mico-Leão-Dourado e Jacaré do papo-amarelo". Também foram utilizados gravações dos sons emitidos pelos animais junto com a percepção tátil. Assim as crianças puderam perceber as características físicas dos animais tais como tamanho, dentição, estruturas que recobrem o corpo como pele, pêlo, pena, casco, e os sons foram relacionados aos animais pertencentes (Line e Mergulhão, 2014).

Segundo Moriwaki e Neiman (2011) a "Trilha do Silêncio", do Parque Estadual do Jaraguá possui placas em Braille, no início com informações sobre sua criação, quanto em seu percurso com nomes das espécies das árvores. Há piso podotátil nas instalações do prédio do centro de visitantes. Outro ponto que merece destaque no parque são os livros em Braille doados pela Secretaria do Meio Ambiente. Os autores criticam, no entanto, o fato dos livros estarem somente em Braille não promovendo a inclusão, mas a exclusão dos que não lêem em Braille, como os servidores do parque, que não podiam dizer sequer do que tratavam, sugerindo que fossem também impressos a tinta.

Em visita ao Jardim Botânico de Brasília foi possível observar um projeto que esta sendo desenvolvido, chamado de "Deficiente Visual na Trilha".

É uma ação social realizada por voluntários e ciclistas de Brasília que decidiram pedalar, com quem de outra forma não teria como fazê-lo, os deficientes visuais (DVs). Para tanto, utilizam bicicletas tandem (bicicletas duplas - para dois ciclistas), na frente vai um condutor, voluntário do projeto e atrás um deficiente visual.

O objetivo do projeto é preparar/ capacitar o deficiente visual para participar de trilhas, passeios e competições de moutain bike e ciclismo, promovendo uma atividade física ao ar livre, em contato com a natureza, em grupo, possibilitando amplas condições de integração, inclusão social, lazer e melhoria da qualidade de vida.

Os passeios são realizados em sábados alternados e em parceria com o CEEDV - Centro de Ensino Especial do Deficiente Visual (Site do "DV na Trilha”).

Outra iniciativa do Jardim Botânico de Brasília que visa a promover a inclusão social dos deficientes visuais é o Jardim Sensorial (Figura 4). Trata-se de um jardim com plantas aromáticas, disposto de tal maneira que os deficientes visuais podem sentir, tocar, cheirar as plantas. Porém não encontramos as placas das plantas em Braille, o que poderia ajudar a informar melhor os deficientes.

A REBIO União em breve contará com outros espaços adaptados para atendimento as pessoas com deficiência como o Centro de Vivências aonde serão trabalhados os sentidos. Segundo Oliveira (2013, p. 3) "através de sons, odores e tato por meio dos próprios recursos da Reserva como frutas, semente, folhas e animais embalsamados vitimados por acidentes ao longo da Rodovia BR 101, próximo à Rebio”.

Outra experiência positiva da inclusão da pessoa com deficiência visual em ambiente natural, foi o ocorrido na Mata da Amem (Associação Metropolitana para Erradicação da Mendicância), atualmente 


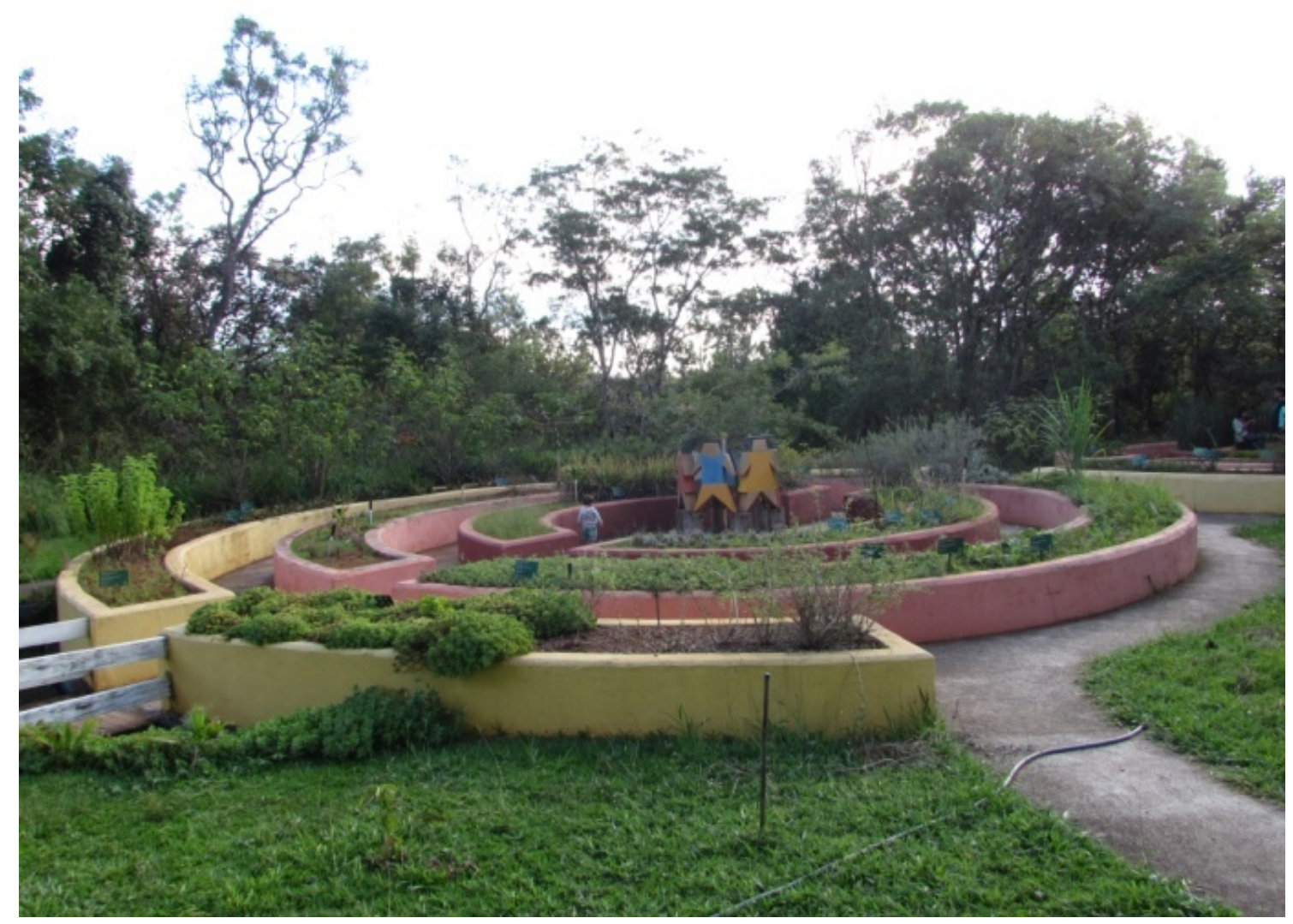

Figura 4. Jardim Sensorial do Jardim Botânico de Brasília.

albergando a Floresta Nacional da Restinga de Cabedelo, no município de mesmo nome, no Estado da Paraíba, como narrado por Souza e Souza (2006). Uma turma de alunos com deficiência visual, das disciplinas de Geografia e História da Paraíba, do Instituto dos Cegos da Paraíba “Adalgisa Cunha”, de João Pessoa, fizeram várias visitas à mata, de modo que puderam vivenciar in loco todo o aprendizado. A experiência ultrapassou o espaço físico da sala de aula, quebrou a rotina dos dias letivos, virou álbum de fotografias e vídeo premiado em festival de Educação Ambiental (Souza e Souza, 1998).

\section{Motora}

O Jardim Botânico de Brasília implantou uma série de infraestruturas que promovem a acessibilidade às áreas de maior visitação das pessoas com dificuldades motoras: rampas, calçadas, banheiros e bebedouros adaptados a cadeirantes, biblioteca para crianças. O local é bem sinalizado, inclusive nas trilhas.
O Parque Nacional de Brasília PNB, também possui uma série de infraestruturas que visam à acessibilidade das pessoas com dificuldades motoras aos pontos de maior interesse liberados para visitação, que são: duas piscinas de água mineral, trilha da capivara, ilha da meditação e centro de visitantes, apresentando as seguintes infraestruturas:

Acessos - Possui rampas de acesso tanto ao prédio da sede quanto do centro de visitantes, além de estacionamento reservado para deficientes mais próximos das piscinas, conta ainda com rampas nas portarias.

Locomoção próxima às piscinas O PNB possui com calçadas e rampas que facilitam o acesso aos deficientes, idosos e crianças.

Emergências - O PNB conta com postos médicos.

Centro de Visitantes - O PNB possui um centro de visitantes adaptado, com rampas, porém sem piso podotátil, onde ocorrem exposições temporárias e 
também onde ficam expostas algumas fotos e uma maquete do Parque Nacional.

Banheiros e bebedouros - Tanto as áreas das piscinas, quanto do centro de visitante possuem banheiros adaptados a cadeirantes. As piscinas contam ainda com vestiários com corredores largos. Nas áreas das piscinas há bebedouros adaptados a cadeirantes e crianças.

Ilha da Meditação - Espaço contemplativo, reservado para ouvir o silêncio segundo sugestão da placa informativa, tem fácil acesso até para cadeirantes.

Trilha da Capivara - Trilha de 1,2 $\mathrm{km}$ circular, com inicio e fim no mesmo ponto, possui cerca de madeira e um terreno com pouca inclinação, possui áreas de descanso com bancos. É possível de ser feita por pessoas de mobilidade reduzida e por cadeirantes acompanhados.

Nessa mesma linha a "Trilha do Silêncio”, do Parque Estadual do Jaraguá, foi adaptada para receber pessoas deficiência e mobilidade reduzida. Toda sua extensão é acompanhada por corrimãos em duas alturas e guias de balizamento, além de ser nivelada, seja por madeiramento ou terra batida, permitindo que cadeirantes circulem pela trilha. Além disso, há banheiros adaptados e sinalizados para cadeirantes (Moriwaki e Neiman, 2011).

Malaggi (2011) diz que outra atividade possível de ser desenvolvida em locais naturais é pedalada com uso de handbike, pois contribui com a locomoção e transporte, sendo uma atividade prazerosa e democrática. Podendo ser usada por pessoas com deficiências motoras variadas.

Segundo Malaggi (2011), a atividade de Jeep Tour ainda é pouco desenvolvida no Brasil. No Rio de Janeiro é realizado um trabalho pioneiro, que conta com carros adaptados para fazer passeios em pontos turísticos da cidade. São automóveis com sistema de travas nas rodas das cadeiras.

Ainda segundo Malaggi (2011), o vôlei adaptado é uma atividade que gera prazer e adrenalina. Usado nas praias do Rio de Janeiro, o esporte é um dos mais praticados por pessoas com deficiências e pode ser desenvolvido em qualquer espaço.

Segundo Oliveira (2013), a REBIO União que está localizada no Estado do Rio de Janeiro, especificamente nos Municípios de Rio das Ostras, Casimiro de Abreu e Macaé, vem adaptando um percurso de 1.000 dos $3.300 \mathrm{~m}$ da Trilha do Pilão para receber pessoas com deficiência.

Essa trilha que vem sendo adaptada como parte do projeto "Reserva Biológica União: uma área natural protegida da Mata Atlântica, acessível aos portadores de necessidades especiais” pela parceria do ICMBio, da Secretaria de Estado do Ambiente do Rio de Janeiro SEA/RJ e do Fundo Brasileiro para a Biodiversidade - Funbio que assinaram um termo de reciprocidade para execução do projeto. (Oliveira, 2013: 3)

\section{Auditiva, mental ou intelectual}

Segundo o Ministério do Turismo (2010), para nos comunicarmos com deficientes auditivos, primeiro devemos chamar-lhes sua atenção ficando de frente para eles ou tocando-lhes gentilmente no braço. Uma boa articulação dos lábios pode facilitar a comunicação, caso ele saiba fazer leitura labial. Ao atender e passar instruções de atividades, devemos olhar diretamente para os deficientes visuais, mesmo que haja um intérprete de LIBRAS (Língua Brasileira de Sinais); caso contrário pode parecer que a mensagem não se dirige a ele.

Da mesma forma, segundo o site bengalalegal, deve-se:

agir naturalmente ao dirigir-se a uma
pessoa com deficiência intelectual.
Trata-as com respeito e
consideração. Se for uma criança,
trate como criança. Se for
adolescente, trate-a como
adolescente. Se for uma pessoa
adulta, trate-a como tal. Não trate
como criança aquelas pessoas que
não o sejam. Não as ignore.
Cumprimente e despeça-se delas
normalmente, como faria com
qualquer pessoa. Dê atenção a elas,
converse e vai ver como será
divertido. Seja natural, diga palavras
amistosas. Não superproteja. Deixe
que ela faça ou tente fazer sozinha
tudo o que puder. Ajude apenas
quando for realmente necessário.
Não subestime sua inteligência. As
pessoas com deficiência intelectual 
levam mais tempo para aprender, mas podem adquirir muitas habilidades intelectuais e sociais.

Para Malaggi (2011), uma das atividades possíveis para pessoas com deficiência auditiva, mental ou intelectual é o “arvorismo”, que é um esporte radical que consiste na travessia entre plataformas montadas no alto das árvores, ultrapassando diferentes tipos de obstáculos como escadas, pontes suspensas, tirolesas e outras atividades que podem ser criadas.

As deficiências não impedem a construção de conhecimentos e fatos, mas as limitam, mesmo com a ajuda de diversos fatores. É importante que as pessoas com deficiência estejam sempre acrescentando novas vivências, como o manuseio de novos objetos e saídas a locais diferentes aos habituais, que proporcionem experiências válidas para novos aprendizados. A integração e a acessibilidade dos deficientes em projetos de educação ambiental podem contribuir como uma grande fonte de aprendizagem, socialização e capacitação desses indivíduos (Line e Mergulhão, 2014).

A Floresta Nacional de Brasília, atualmente, não é acessível, por isso as sugestões aqui apresentadas buscam nortear a realização de adaptações para incluir socialmente as pessoas com deficiências nas atividades de educação ambiental ou a simples contemplação da Natureza.

Para o Ministério do Turismo (2010) para a "adaptação de atividades e equipamentos, é fundamental contar com a participação de pessoas com deficiência e testar essas adaptações em situações controladas, porém reais”. Consideramos pertinente que as estruturas, caso venham a ser implantadas, possam receber outras contribuições de entidades e associações ligadas à causa de acessibilidade.

Em primeiro lugar, corroborando Sandoval (2002), os servidores da FLONA de Brasília devem estar aptos a identificar os riscos da área em que trabalham, tais como: insetos, cobras e plantas venenosas. Devem ser capacitados para prestarem os primeiros socorros em casos de emergência. Devem ser motivados a se capacitarem em outras formas de comunicação, tais como, Braille, linguagem dos sinais, gráficos e métodos alternativos para que possam se comunicar em caso de emergência. Enfim, se os servidores não estiverem sensibilizados e não se envolverem com relação ao respeito e a inter-relação com os deficientes, nenhuma estrutura adaptada será suficiente, nenhum projeto de acessibilidade terá êxito.

Diante disso, no processo de sensibilização dos servidores são relevantes as dicas e recomendações do Ministério do Turismo no trato com pessoas com deficiências (Ministério do Turismo, 2010: 28):

\begin{abstract}
- Trate pessoas com deficiência ou mobilidade reduzida com naturalidade. Não há motivo algum para tratá-las com preocupação ou atenção excessivas.

- Seja direto e ofereça ajuda sempre. Caso a oferta seja recusada, não insista. Pessoas com deficiência podem realizar muitas atividades e tarefas sozinhas.

- Quando o cliente aceitar ajuda, siga suas orientações. Muitas pessoas com deficiência desenvolvem técnicas pessoais e sabem melhor do que ninguém como devem ser auxiliados. Relaxe, seja espontâneo. Não há problema algum em utilizar expressões cotidianas como "nos vemos mais tarde", mesmo quando lidamos com pessoas com deficiência visual.

- Ao comunicar-se com pessoas com deficiência ou mobilidade reduzida, não as trate como incapazes. Se elas aceitarem ajuda, não estenda isso para outras atividades e funções para as quais elas afirmam não precisar de auxílio. Além disso, não exagere no cuidado e não trate adultos como crianças pequenas.

- Seja paciente. Algumas pessoas precisam de mais tempo para se expressar, se movimentar ou compreender instruções.

- Fale diretamente à pessoa com deficiência mantendo contato visual e não ao acompanhante ou intérprete. - Não alimente ou distraia cães-guia nem brinque com eles sem a permissão do seu dono. Lembre-se de que eles estão trabalhando!
\end{abstract}

Segundo Sandoval (2002) a sinalização dos espaços possíveis de serem 
acessados pelas pessoas com deficiência é fundamental e a simbologia usada deve ser uniforme em todas as áreas protegidas para que os usuários possam compreender a informação independente da Unidade de Conservação que esteja. Nesse sentido, a Assessoria de Comunicação do ICMBio deve ser envolvida no processo para que a linguagem a ser utilizada nas sinalizações da Flona de Brasília sejam as mesmas das demais unidades de conservação do Brasil.

As adaptações de mobilidade do prédio da sede devem ser providenciadas com a maior brevidade possível. A desobstrução do banheiro de adaptado aos cadeirantes é urgente e necessária, assim como a construção de vestiários com banheiros externos adaptados.

$O$ respeito às normas de reserva de vagas nos estacionamentos também é premente. Uma alternativa seria buscar o apoio do Departamento de Estradas e Rodagens (DER) do Distrito Federal ou do Departamento de Transito do Distrito Federal (Detran/DF).

A sala de recepção dos visitantes, que está em reforma, ainda que não adaptada para deficientes visuais, poderá ser interessante para a maioria das pessoas que tem mobilidade reduzida, pois haverá ali uma exposição permanente de fotos retiradas no interior da Unidade de Conservação. Porém, a adaptação da sala aos deficientes visuais seria muito interessante, pois os animais taxidermizados que já se encontram na Flona de Brasília e outros que porventura a UC possa conseguir junto ao Centro de Triagem de Animais Silvestres (Cetas), ou mesmo junto ao Zoológico de Brasília, poderiam compor um museu tátil, poder-se ia ainda executar sons desses animais quando ocorressem visitas de deficientes visuais, como no trabalho realizado em Sorocaba-SP, por Line e Mergulhão (2014).

$\mathrm{O}$ jardim sensorial, nos moldes do encontrado no Jardim Botânico de Brasília, pode ser uma opção muito construtiva para os deficientes visuais, cadeirantes, idosos e crianças haja vista que a ideia surgiu exatamente para amenizar toda essa dificuldade, além de proporcionar para esta parcela da sociedade o contato com a natureza. Como no Jardim Botânico de Brasília, o jardim sensorial deverá ficar suspenso a uma altura pré-determinada, considerando passagem tanto para cadeirantes quanto deficientes visuais e idosos. Este recurso garante o livre acesso a todos que queiram tocar ou cuidar das espécies com facilidade.

A Flona de Brasília é usada por várias pessoas para atividades físicas de caminhada e corrida, inclusive o Joaquim Cruz, medalhista olímpico, desenvolve um projeto chamado "Rumo ao Pódio Olímpico" e um dos lugares usados por seus alunos para treinar é a Área 1 da FLONA de Brasília. Nesse sentido, pode-se implantar o vôlei adaptado para deficientes físicos, pois trata-se de um esporte democrático e que pode ser praticado, num pequeno espaço. A administração da unidade poderia disponibilizar um espaço e buscar parceiros para viabilizar a estrutura física.

Aproveitando a vocação de passeios ciclísticos da Flona de Brasília, o projeto "Deficiente Visual na Trilha" desenvolvido no Jardim Botânico seria de fácil implantação, uma vez que a flona possui cerca de $90 \mathrm{~km}$ de estradas de terra. Um primeiro passo seria o contato com os administradores do projeto e a busca de parcerias junto aos grupos de ciclistas que frequentam a Flona de Brasília.

O jeep tour para cadeirantes é perfeitamente possível e adaptável nas caminhonetes já usadas pelos servidores para transitar pela unidade. Seria interessante, porém, que uma vez adaptado o carro, os passeios fossem pré-agendados para não chocar com as atividades normais da gestão da unidade. Ou de outro modo, poderia buscar parceria empresariais para a doação de um ou dois automóveis adaptados.

O projeto de arvorismo executado pelo Ministério do Turismo seria perfeitamente possível de ser implantado na Flona de Brasília, uma vez que, como já foi dito, a unidade é composta, além da vegetação de cerrado, por plantios de Pinus e Eucaliptus, inclusive próximo à área da sede.

A criação de uma trilha adaptada na Floresta Nacional de Brasília seria uma maneira de promover a inclusão social. Segundo Rodrigues e Ferreira (2013), as trilhas interpretativas são efetivas quando 
falamos em educação ambiental, podendo ser adaptadas as pessoas com deficiências. Para sua implantação deve ocorrer um levantamento prévio do relevo e dos locais que representem algum perigo para cadeirantes ou pessoas que precisem de apoio para andar. A presença de monitores, de preferência aptos em comunicação por LIBRAS, é fundamental. É preciso atentar também para o tipo de solo, que sendo escorregadio, pode provocar escorregões e o descontrole de cadeiras de roda, sendo o ideal a construção de passadiços, com estruturas de corrimões para apoio manual e transição de quaisquer acidentes de relevo, viabilizando assim o acesso a cadeirantes.

Além disso, segundo Rodrigues e Ferreira (2013), corroborando Julião e Ikemoto (2006), vários estímulos( sonoros, como o canto dos pássaros; táteis, das cascas das árvores e olfativos, como o cheiro de flores e frutos) podem ser experimentados pelos deficientes visuais ao longo da trilha.

Para Leite et al. (2006, p. 1):

O objetivo geral de uma trilha é promover uma visita agradável, relaxante, descontraída, informativa e enriquecedora, em que o grupo perca seus hábitos urbanos e tenha um contato mais íntimo, havendo uma correlação intrínseca entre homem e natureza. A essência está em aproveitar o caminho, ao invés de simplesmente chegar.

Outra observação pertinente segundo Sampaio e Guimarães (2009), são os pontos de parada para descanso nas trilhas interpretativas, onde o grupo pode ser chamado a um momento de aprendizado e reflexão. É importante, segundo Sandoval (2002) a sinalização convencional e em Braille, das espécies de árvores encontradas ao longo do caminho.

Foi elaborado uma sugestão de trilha, nomeada de "Trilha do Vovô". A sugestão aqui apresentada passa por um trecho de Cerrado bem preservado próximo à Sede. O relevo é bastante plano e tem duas opções de percurso, um maior de $1.500 \mathrm{~m}$ e o menor de $900 \mathrm{~m}$, sendo que o de $1.500 \mathrm{~m}$ chega até um campo de murundus, que é constituído por uma área plana, inundável no período das chuvas, onde se encontram inúmeros morrotes (Resende et al., 2004).

A trilha a ser aberta para ser acessível deve levar em consideração os itens discutidos como a: construção de passadiços ou calçadas, identificação das árvores ao longo do caminho, sinalização, inclusive em braile; corrimões nas laterais, pontos de parada para descanso. É claro que a sugestão poderá ser ajustada em conjunto com as entidades que cuidam dos interesses das pessoas com deficiência.

Além das adaptações necessárias ao atendimento da legislação, do acesso ao prédio da sede e da sinalização de uma forma geral. Considero que todas as alternativas encontradas nas unidades de conservação e espaços naturais descritas nesse trabalho podem ser implantadas na Flona de Brasília, no entanto, algumas merecem destaque, tais como: sala de visitantes com exposição de fotos, disponibilização dos animais taxidermizados para os deficientes visuais, jardim sensorial, passeio ciclístico em bicicletas duplas com os deficientes visuais, jeep tour para cadeirantes, vôlei adaptado para deficientes físicos, arvorismo para deficientes auditivos e mentais e trilha interpretativa adaptada para todas as pessoas com deficiência, principalmente motora.

Mesmo com citações de alguns exemplos, observa-se que a necessidade de adaptação de lugares públicos ainda é pouco reconhecida, especialmente em Unidades de Conservação, onde pouca ou nenhuma estrutura é adequada para receber este público (Oliveira et al., 2013).

\section{Conclusão}

Muito se fala de inclusão social, porém, pouco tem sido feito para realmente fazer com que os excluídos socialmente possam participar ativamente das atividades recreativas e educacionais, de maneira especial, as atividades de educação ambiental em áreas protegidas, que em raras exceções são planejadas no sentido de incluir os deficientes, ou mesmo as pessoas com mobilidade reduzida, como é o caso dos idosos.

$\mathrm{O}$ que se buscou com esse trabalho foram alternativas a esse desafio. Todavia, 
em todas as ações que porventura vierem a ser tomadas neste sentido os grupos que representam as pessoas com deficiência física, não só podem como deverão ser chamadas para opinarem e participarem ativamente das decisões.

\section{Declaração de conflito de interesses}

Os autores declaram não haver

conflitos de interesses.

\section{Referências}

Bengala Legal. Disponível em: <http://www. bengalalegal.com/lidar $>$. Acesso em: 20 maio 2015.

Brasil. Leis, decretos, etc. Decreto $\mathbf{s} / \mathbf{n}^{\circ}$ de 10 de junho de 1999. Autoriza a União a aceitar doação de imóveis que menciona, cria a Floresta Nacional de Brasília. Disponível em: <http://www.planalto.gov.br/ccivil_03/DNN/

Anterior a 2000/1999/Dnn8127.htm>. Acesso em: 01 maio 2015.

Brasil. Leis, decretos, etc. Decreto $\mathbf{n}^{0}$ 3.298, de 20 de dezembro de 1999. Dispõe sobre a Política Nacional para a Integração da Pessoa Portadora de Deficiência, consolida as normas de proteção. Disponível em: <http://www. planalto.gov.br/ccivil_03/decreto/d3298.htm>.

Acesso em: 04 maio 2015.

Brasil. Leis, decretos, etc. Decreto $\mathbf{n}^{0}$ 5.296, de 2 de dezembro de 2004. Estabelece normas gerais e critérios básicos para a promoção da acessibilidade das pessoas portadoras de deficiência ou com mobilidade reduzida. Disponível em: <http://www.planalto.gov.br/ ccivil_03/_ato2004-2006/2004/decreto/

d5296.htm>. Acesso em: 02 maio 2015.

Brasil. Leis, decretos, etc. Decreto $n^{0}$ 6.949, de 25 de agosto de 2009. Promulga a Convenção Internacional sobre os Direitos das Pessoas com Deficiência e seu Protocolo Facultativo, assinados em Nova York, em 30 de março de 2007. Disponível em: <http://www.planalto. gov.br/ccivil_03/_ato2007-2010/2009/decreto/ d6949.htm>. Acesso em: 15 abr. 2015.

Brasil. Leis, decretos, etc. Lei $\mathbf{n}^{0}$ 9.795, de 27 de abril de 1999. Dispõe sobre a educação ambiental, institui a Política de Educação Ambiental. Disponível em: <http://www. planalto.gov.br/ccivil_03/leis/19795.htm>.

Acesso em: 28 abr. 2015.

Brasil. Leis, decretos, etc. Lei $\mathbf{n}^{\mathbf{0}} \mathbf{9 . 9 8 5}$, de 18 de julho de 2000. Institui o Sistema Nacional de Unidades de Conservação da Natureza. Disponível em: <http://www.planalto.gov.br/ ccivil_03/leis/19985.htm>. Acesso em: 28 abr. 2015.

Brasil. Conselho Nacional de Trânsito CONTRAN. Resolução $\mathbf{n}^{0}$ 303, de 18 de dezembro de 2008. Dispõe sobre as vagas de estacionamento de veículos destinadas exclusivamente às pessoas idosas. Disponível em: <http://www.denatran.gov.br/download/ resolucoes/republicacao_resolucao_contran_303 _08.pdf>. Acesso em: 10 maio 2015.

Brasil, Conselho Nacional de Trânsito CONTRAN. Resolução $\mathbf{n}^{\mathbf{0}}$ 304, de 18 de dezembro de 2008. Dispõe sobre as vagas de estacionamento destinadas exclusivamente a veículos que transportem pessoas portadoras de deficiência e com dificuldade de locomoção. Disponível em: <http://www.denatran.gov.br/ download/resolucoes/resolucao_contran_304. pdf>. Acesso em: 10 maio 2015.

Brasil. Secretaria de Educação Fundamental. Parâmetros Curriculares Nacionais: meio ambiente e saúde. Brasília, MEC, 1997. Disponível em: <http://portal.mec.gov.br/seb/ arquivos/pdf/livro091.pdf $>$. Acesso em: 12 maio 2015.

Coelho, H. A.; Galvão, H. F; Derschum, F. G.; Avelino, A. S. Plano operativo de prevenção e combate aos incêndios florestais da Floresta Nacional de Brasília. Brasília: IBAMA, 2007. Disponível em: <http://www.ibama.gov.br/ phocadownload/category/44-p?download= 2327>. Acesso em: 01 maio 2015.

DV na Trilha. Disponível em: <http://www.dvnatrilha.com.br/parceiros.html>. Acesso em: 10 maio 2015.

Dias, G. F. Educação ambiental: princípios e práticas. 7. ed. São Paulo: Gaias, 2001.

IBGE. Censo Demográfico 2010: características gerais da população, religião e pessoas com deficiência. Disponível em: <http://www.ibge.gov.br/home/estatistica/ populacao/censo2010/caracteristicas_religiao_ deficiencia/default_caracteristicas_religiao_ deficiencia.shtm>. Acesso em: 05 maio 2015.

IBGE. Censo Demográfico 2010: resultados gerais da amostra. Disponível em: <http://www.ibge.gov.br/home/presidencia/noti cias/imprensa/ppts/00000008473104122012315 727483985.pdf > . Acesso em: 01 maio 2015.

ICMBio. Flona de Brasília. s.d. Disponível em: $<$ http://www.icmbio.gov.br/portal/biodiversidad e/unidades-de-conservacao/biomasbrasileiros/cerrado/unidades-de-conservacaocerrado/2070>. Acesso em: 10 maio 2015.

ICMBio. Mapa com os limítes kml. Disponível em: $\quad<$ http://www.icmbio.gov.br/ portal/biodiversidade/unidades-de-conservacao/ biomas-brasileiros/cerrado/unidades-de- 
conservacao-cerrado/2070-flona-de-

brasilia.html>. Acesso em: 24 abr. 2015.

Julião, D. P.; Ikimoto, S. M. O direito ao lazer do deficiente visual em áreas naturais públicas e unidades de conservação. Disponível em: $<$ http://www.ivt-rj.net/sapis/2006/pdf/

DanielleJuliao.pdf>. Acesso em: 20 abr. 2015.

Leite, E.; Botinha, F. S.; Almeida, F. C. M.; Souza, G. R. Trilhas interpretativas como atividade de Educação Ambiental. Belo Horizonte: PUCMinas, 2006. Disponível em: $<$ http://www.pucminas.br/graduacao/cursos/arq uivos/n8ARE_ARQ_REVIS_ELETR20060927 111902.pdf?PHPSESSID=ac4302ab0924b5028 2a0ecc01b9df109>. Acesso 21 maio 2015.

Line, J. P.; Mergulhão, M. C. Educação Ambiental e inclusão social: participação de crianças em atividade de Educação Ambiental. REB, v. 7, n. 2, p. 193-209, 2014. Disponível em: <http://revistas.pucsp.br/index.php/reb/ article/viewFile/15294/15155>. Acesso em: 15 abr. 2015.

Malaggi, M. Adequação de práticas para portadores de necessidades especiais em atividades de ecoturismo: estudo de caso. Medianeira: Universidade Tecnológica Federal do Paraná, 2011. (Trabalho de conclusão do Curso Superior em Tecnologia em Gestão Ambiental).

Mergulhão, M. C; Vasaki, B. N. G. Educando para a conservação da Natureza: sugestões de atividades em Educação Ambiental. São Paulo: EDUC, 1998.

Ministério do Turismo. Manual de boas praticas: acessibilidade em ecoturismo e turismo de aventura. 1. ed. Belo Horizonte, 2010. Disponível em: <http://turismoadaptado. wordpress.com/2011/05/25/manual-de-boaspraticas-de-acessibilidade-em-ecoturismo-eturismo-de-aventura/>. Acesso em: 18 maio 2015.

MMA. Diretrizes para visitação em unidades de conservação. Ministério do Meio Ambiente, Secretaria de Biodiversidade e Florestas. Brasília: MMA, Diretoria de Áreas Protegidas, 2006. 70 p. Disponível em: $<$ http://www.mma.gov.br/estruturas/ascom_ boletins/_arquivos/livro.pdf $>$. Acesso em: 05 maio 2015.

Moriwaki, E. M.; Neiman, Z. Acessibilidade para pessoas com deficiência visual em Unidades de Conservação: estudo de caso do Parque Estadual do Jaraguá (SP). Anais do VIII Congresso Nacional de Ecoturismo e do IV Encontro Interdisciplinar de Ecoturismo em Unidades de Conservação. Revista Brasileira de Ecoturismo, São Paulo, v. 4, n. 4, p. 523, 2011. Disponível em: <www.sbecotur.org.br/ rbecotur/seer/index.php/ecoturismo/article/view/ 192/138>. Acesso em: 04 maio 2015.

Oliveira, L. M. B. Cartilha do Censo 2010. Pessoas com deficiência. Brasília 2012. Disponível em: <http://www.pessoa comdeficiencia.gov.br/app/sites/default/files/pu blicacoes/cartilha-censo-2010-pessoas-comdeficienciareduzido.pdf $>$. Acesso em: 04 maio 2015.

Oliveira, D. N.; Souza, J. N. S.; Erika, C.; Miranda, B. D.; Gomes, O. V. O. Acessibilidade a ambientes naturais para pessoas com deficiência. IV Congresso Brasileiro de Gestão Ambiental, Salvador/BA - 25 a 28/11/2013. 6 p. Disponível em: <http://www.ibeas.org.br/ congresso/Trabalhos2013/VII-066.pdf $>$. Acesso em: 14 maio 2015.

Paz, R. J. As pessoas portadoras de deficiência no Brasil: inclusão social. João Pessoa: Ed. Universitária/UFPB, 2006a.

Paz, R. J. Meio ambiente, ecologia e ensino. In: Paz, R. J. (Org.). Fundamentos, reflexões e experiências em Educação Ambiental. João Pessoa: Editora Universitária/UFPB, 2006 b. p. 19-41.

Paz, R. J.; Freitas, G. L.; Souza, E. A. Áreas protegidas na legislação brasileira. In: Paz, R. J.; Farias, T. (Orgs.). Gestão de áreas protegidas: processos e casos particulares. João Pessoa: Editora Universitária/UFPB, 2008. p. 21-40.

Paz, R. J.; Freitas, G. L.; Souza, E. A. Unidades de conservação no Brasil: história e legislação. João Pessoa: Editora Universitária/ UFPB, 2006.

Resende, A. P. C.; Vital, F. M. P. (Org.). A Convenção sobre os Direitos das Pessoas com Deficiência comentada. Brasília: Corde, 2008. Disponível em: <http://www.governoeletronico. gov.br/biblioteca/arquivos/a-convencao-sobreos-direitos-das-pessoas-com-deficienciacomentada>. Acesso em: 10 mar. 2015.

Resende, I. L. M.; Araújo, G. M.; Oliveira, A. P. A.; Oliveira, A. P.; Ávila Júnior, R. S. A comunidade vegetal e as características abióticas de um campo de murundu em Uberlândia, MG. Acta bot. bras., v. 18, n. 1, p. 9-17, 2004.

Rodrigues, P. H. C.; Ferreira, R. M. Educação Inclusiva: trilha interpretativa. Revista Jurídica, v. 13, n. 21, 2013. Disponível em: $<$ http://revistas.unievangelica.edu.br/index.php/ revistajuridica/article/download/707/690>.

Acesso em: 21 maio 2015.

Sampaio, S. M. V.; Guimarães, L. B. Educação Ambiental: tecendo trilhas, escriturando territórios. Educ. rev., v. 25, n. 3, p. 353-368, 2009. Disponível em: <http://www.scielo.br/ 
pdf/edur/v25n3/17.pdf>. Acesso em: 21 maio 2015.

Sandoval, R. J. Guia de cómo hacer un diagnóstico de accesibilidad en um área protegida. Proyecto de Accesibilidad a Parques Naciones y/o Áreas Protegidas. San José, Costa Rica: FUNDECOOPERACIN, 2002.

Santos, M. M.; Garcia, J. G. L.; Arias, F. Catálogo de buenas prácticas en materia de accesibilidad en espacios naturales protegidos. Madrid: Europarc, 2007. Disponível em: <http://www.redeuroparc.org/ documentos_anexos/Publicaciones/ligadas_a_ plan_de_accion/manual_5.pdf $>$. Acesso em: 28 abr. 2015.

Sassaki, R. K. Terminologia sobre deficiência na era da inclusão. In: Vivarta, V. (Coord.). Mídia e deficiência. Brasília: Andi/Fundação Banco do Brasil, 2003. p. 160-165. Disponível em: <http://www.cepde.rj.gov.br/terminologia_ ppds.doc $>$. Acesso em: 04 maio 2015.
Souza, M. S. B.; Souza, E. A. Era uma vez... In: Paz, R. J. (Org.). Fundamentos, reflexões e experiências em Educação Ambiental. João Pessoa: Editora Universitária/UFPB, 2006. p. 263-271.

Souza, M. S. B.; Souza, E. A. Ver pra quê? 1998; Vídeo; VHS. Festival de Vídeo sobre Educação Ambiental; $2^{\circ}$ Lugar. Brasília: União Latino-Americana de Mulheres - ULAM.

Informação da Licença: Este é um artigo Open Access distribuído sob os termos da Licença Creative Commons Attribution, que permite uso irrestrito, distribuição e reprodução em qualquer meio, desde que a obra original seja devidamente citada. 